\title{
Analisis Ekonomi Penggunaan Tepung Kiambang (Salvinia Molesta) Terfermentasi dalam Ransum Ayam Jawa Super
}

\section{Economic Analysis Fermented Kiambang Flour (Salvinia Molesta) in Super Javanese Chicken Ration}

\author{
A P Tanjung ${ }^{1}$, T Rumiyani ${ }^{1 *}$, dan Nurhayati ${ }^{1}$ \\ ${ }^{1}$ Jurusan Peternakan Politeknik Negeri Lampung, \\ Jln. Soekarno Hatta No 10 Rajabasa Bandar Lampung, 35144 \\ * E-mail korespondensi: trirumiyani@polinela.ac.id
}

\begin{abstract}
This study aimed to analyze the production cost of using fermented kiambang flour in Super Javanese chicken ration. The research method used descriptive method. Data collection was done by taking samples from controls and treatment with a total of 15 heads each at the end of maintenance. The average yield on the administration of fermented kiambang flour of 10\% resulted in an IOFC value of Rp. 13,553 and control resulted in an IOFC value of Rp. 12,868. The average yield on the administration of fermented kiambang flour 10\% produces a BEP value of Rp. 31,584 and control produces a BEP value of Rp. 33,636. The average yield on the administration of fermented kiambang flour $10 \%$ produces an $R / C$ value of 1,215 and at the control stage produces an $R / C$ value of 1,180 . The average yield on the administration offermented kiambang flour of $10 \%$ produces a $B / C$ value of 0.215 and at the control stage produces a B/C value of 0.180. It can be concluded that the use of fermented kiambang flour as much as $10 \%$ on super Javanese chicken rations can reduce production costs and have economic value.
\end{abstract}

Keywords: : economic analysis, fermented kiambang flour, super Javanese chicken

Diterima: 18 September 2020, disetujui 20 Desember 2020

\section{PENDAHULUAN}

Pakan merupakan proporsi biaya terbesar (70\%) dalam usaha peternakan (Ketaren, 2010). Pengunaan pakan yang baik akan menekan biaya produksi pada suatu pemeliharaan peternakan. Pakan yang digunakan untuk unggas berupa $50-60 \%$ berasal dari jagung sebagai sumber energi. Tingginya penggunaan jagung pada pakan ayam kampung mengakibatkan biaya pakan menjadi tinggi. Oleh karena itu perlu dilakukan penggunaan bahan baku alternatif yang memiliki kandungan hampir sama seperti jagung yaitu tanaman kiambang.

Kiambang merupakan tanaman air yang hidup terapung pada permukaan air, banyak terdapat pada rawa, sawah, kolam, dan danau. Tingkat pertumbuhan kiambang yang cepat menjadikan tanaman gulma air yang menggangu pada saluran irigasi didaerah persawahan. Provinsi Lampung masih sedikit pemanfaatan kiambang sebagai bahan pakan untuk ternak, terutama ternak unggas. Kandungan yang terdapat pada kiambang berpotensi sebagai bahan pakan untuk ternak unggas, namun tingginya serat kasar pada kiambang menjadi masalah untuk diberikan keternak unggas secara langsung.

Ayam jawa super merupakan hasil persilangan ayam ras petelur dengan ayam kampung lokal. Adapun karakteristik ayam kampung super yaitu dapat diproduksi dalam jumlah banyak dengan bobot seragam, laju pertumbuhan lebih cepat daripada ayam kampung, memiliki tingkat kematian yang rendah, mudah beradaptasi dengan lingkungan serta memiliki cita rasa yang tidak berbeda dengan ayam kampung (Kaleka, 2015). Usia panen ayam jawa super yang cukup lama menjadikan harga jual ayam cukup tinggi, hal ini dikarenakan setiap hari ayam harus diberikan pakan yang dibutuhkan. 
Kiambang merupakan tumbuhan yang hidup di air yang biasanya berada di rawa-rawa atau pada kolamkolam ikan. Belum adanya pemanfaatan kiambang sebagai bahan pakan, memiliki peluang untuk menekan biaya produksi pakan karena untuk memperoleh kiambang hanya perlu bermodalkan transportasi. Namun untuk memberikan kiambang secara langsung kepada ternak terutama unggas perlu dilakukan pengolahan pakan terlebih dahulu yaitu dengan cara fermentasi.

Kiambang dikatakan memiliki nilai ekonomis yang cukup untuk menekan biaya produksi pakan, namun untuk melihat nilai ekonomis perlu adanya analisa secara ekonomis untuk mengatakan kiambang tersebut berdampak ekonomis terhadap ransum ayam jawa super. Analisis ekonomi ayam jawa super memiliki kriteria analisa seperti break event point (BEP), income over feed cost (IOFC), revenue cost ratio (R/C) dan benefit cost ratio $(\mathrm{B} / \mathrm{C})$. Penelitian ini bertujuan untuk menganalisis ekonomi penggunaan tepung kiambang terfementasi pada ransum ayam jawa super.

\section{METODE PENELITIAN}

Penelitian ini dilaksanakan di kandang ternak Politeknik Negeri Lampung dan untuk meneliti kandungan nutrisi kiambang terfermentasi dilakukan di Laboratorium Analisis Teknologi Hasil Pertanian Politeknik Negeri Lampung.

\section{Bahan dan Alat}

Bahan yang digunakan dalam penelitian ini adalah doc ayam jawa super 100 ekor, kiambang, dan pakan komersil. Alat yang digunakan dalam penelitian adalah peralatan sanitasi, brooder, tempat pakan dan minum, timbangan, kompor, plastic polietilen dan pisau.

\section{Jenis Penelitian}

Penelitian ini menggunakan percobaan lapang dengan 2 perlakuan yaitu menggunakan pakan komersil $100 \%$ (P0) dan menggunakan pakan komersil $90 \%+10 \%$ tepung kiambang terfermentasi (P1). Penelitian dilakukan menggunakan ayam jawa super dengan jumlah 100 ekor di bagi menjadi 2 kelompok. Setiap kelompok terdiri dari 50 ekor ayam jawa super. Perlakuan diberikan pada umur ke 8 hari-hari ke 90. Ransum yang digunakan pada penelitian ini adalah BR1 saat fase starter dan BR2 saat fase finisher. Hasil data penelitian kemudian dianalisis menggunakan analisis deskriptif.

\section{Fermentasi Kiambang}

Kiambang fase 3 yang basah dikeringkan dengan sinar matahari, setelah kering kemudian digiling halus menjadi tepung. Kiambang tersebut dicampur dengan molases dengan perbandingan $1 \mathrm{~kg}$ kiambang dicampur dengan dua sendok makan molases. Setelah molases tercampur rata dengan kiambang, kiambang tersebut dikukus selama $1 / 2$ jam dan dibiarkan dingin. Setelah dingin, kiambang difermentasi dengan mencampurkannya dengan ragi tempe (1 kg kiambang : $18 \mathrm{~g}$ ragi tempe) dan dimasukkan ke dalam bak fermenter dan ditutup dengan plastik. Proses fermentasi berlangsung secara anaerob selama 7 hari. Setelah dilakukan fermentasi selama 7 hari, kiambang kemudian dicetak menjadi butiran-butiran pellet menggunakan gilingan daging yang dimodifikasi, kemudian dikeringkan menggunakan panas matahari (Zaman, et al. 2013).

\section{Variabel yang Diamati dan Analisis Data}

Variabel yang diamati pada penelitian ini

- break event point (BEP), merupakan keadaan dimana dalam menjalankan usaha tidak mengalami kerugian dan keuntungan (Munawir, 2000).

$$
B E P=\frac{\text { total biaya produksi }}{\text { jumlah produksi }}
$$

- income over feed cost (IOFC), merupakan perhitungan berdasarkan harga penjualan ayam dikurangi biaya pakan yang dihabiskan selama periode pemeliharaan (Yamin, 2008)

$\mathrm{IOFC}=$ Pendapatan pemeliharaan-biaya pakan 
- revenue cost ratio, merupakan besarnya biaya penerimaan yang diterima dalam produksi (Soeharjo dan Patong, 1973)

$$
R / C=\frac{\text { penerimaan }}{\text { biaya produksi }}
$$

- benefit cost ratio, merupakan perbandingan antara keuntungan dengan biaya yang dikeluarkan ( Rahardi dan Hartono, 1993).

Data yang diperoleh dianalisa secara deskriptif.

$$
B / C=\frac{\text { keuntungan }}{\text { biaya produksi }}
$$

\section{HASIL DAN PEMBAHASAN}

Hasil analisis ekonomi penelitian penggunaan tepung kiambang terfermentasi dalam ransum ayam jawa super disajikan pada Tabel 1 berikut :

Tabel 1. Analisis ekonomi ayam jawa super dengan penggunaan tepung kiambang terfermentasi dalam ransum.

\begin{tabular}{lcc}
\hline \multicolumn{1}{c}{ Variabel } & P0 & P1 \\
\hline BEP (Rp.) & $33.636 \pm 2689,45$ & $31.584 \pm 997,04$ \\
IOFC ( Rp.) & $12.868 \pm 1.271,29$ & $13.553 \pm 544,11$ \\
R/C & $1,180 \pm 0,0222$ & $1,215 \pm 0,010317$ \\
B/C & $0,180 \pm 0,0222$ & $0,215 \pm 0,010317$ \\
\hline
\end{tabular}

Sumber : Hasil pengolahan data 2020

Keterangan:

P0 : Tanpa menggunakan kiambang terfermentasi

P1 : Menggunakan kiambang terfermentasi

\section{Analisis Break Event Point (BEP)}

Perbedaan BEP antara P0 dan P1 dengan selisih perbedaan sebanyak Rp. 2.052,-. Perbedaan pada Tabel 1 tersebut disebabkan oleh perbedaan rataan biaya cost produksi. Selisih yang dihasilkan akibat penggunaan kiambang terfermentasi dengan persentase $10 \%$ dalam ransum pada P1. Tingginya rataan BEP pada P0 akibat tingginya rataan biaya pakan pada P0 dibandingkan dengan P1. Sehingga BEP yang dihasilkan pada P0 lebih tinggi dibandingkan dengan P1.

BEP yang dihasilkan merupakan harga minimal untuk penjualan usaha apabila kurang dari harga minimal maka usaha tersebut akan mengalami kerugian. Hal ini sesuai dengan pendapat Thamrin, et al. (2006) yang menyatakan, apabila hasil penjualan usaha hanya mencapai titik BEP harga maka usaha tersebut tidak mengalamin kerugian dan keuntungan (impas) sedangkan apabila menjual hasil produksi di atas BEP harga maka usaha tersebut mendapat pendapatan, sebaliknya apabila menjual hasil produksi dibawah dari BEP harga maka usaha tersebut mengalami kerugian. BEP pada P0 lebih tinggi dibanding dengan P1 hal ini mengakibatkan titik impas P0 lebih besar dibanding dengan P1. Semakin tinggi nilai BEP yang didapatkan maka semakin tinggi resikonya, karena memungkinkan perusahaan tidak mampu untuk menutup seluruh biaya yang dikeluarkan (Ariyanti, 2014).

\section{Analisis Income Over Feed Cost (IOFC)}

Nilai IOFC antara P0 dan P1 menggunakan nilai harga penjualan harga ayam sebesar Rp. 50.000,-/kg bobot hidup. Berdasarkan Tabel 1terdapat perbedaan antara P0 dan P1 dengan rataan IOFC tertinggi terdapat pada $\mathrm{P} 1$ yang disebabkan oleh faktor bobot badan rata- rata $\mathrm{P} 0$ yang dihasilkan lebih tinggi dibanding dengan P1, sehingga rataan pendapatan yang diperoleh lebih tinggi P0 daripada P1. Namun biaya pakan yang digunakan pada P1 lebih rendah dibandingkan dengan P0 sehingga rataan IOFC yang dihasilkan lebih tinggi pada P1. Bobot badan rata- rata P0 dengan nilai 795 P1 dengan nilai 767 memiliki selisih hanya 28 gram yaitu, hal ini mengakibatkan selisih pendapatan yang diperoleh antara P1 dan P0. Nilai rataan IOFC P1 sebesar Rp. 
Tanjung dkk. : Analisis Ekonomi Penggunaan Tepung Kiambang (Salvinia Molesta) Terfermentasi dalam Ransum Ayam Jawa Super 2 (2): 42-46

13.553 dan rataan nilai P0 sebesar Rp. 12.868. Perbedaan yang terjadi antara nilai rata - rata IOFC P1 dan P0 hanya memiliki selisih Rp. 685. Perbedaan IOFC terjadi karena faktor bobot tubuh dan biaya pakan.

Bobot tubuh dipengaruhi nutrisi pakan yang dikonsumi seperti kandungan nutrisi protein, semakin tinggi kandungan protein semakin baik pula nilai nutrisi pakan tersebut. Kandungan nutrisi protein pada P0 yaitu 19$21 \%$ sedangkan pada P1 yaitu 17,53\%-19,33\% selisih yang dihasilkan tidak terlalu besar yaitu 1,5-1,7 \%. (Rizal, 2006) menyatakan bahwa konsumsi protein yang tinggi akan menghasilkan pertumbuhan yang lebih cepat sehingga juga berpengaruh pada bobot tubuh.

Hal ini mengakibatkan bobot tubuh rata-rata antara P0 dan P1 tidak memiliki selisih yang jauh, sehingga IOFC yang dihasilkan pun tidak memiliki selisih yang jauh. Menurut Rasyaf (2011) menyatakan bahwa semakin tinggi nilai IOFC akan semakin baik pula pemeliharaan yang dilakukan, karena tingginya IOFC berarti penerimaan yang didapat dari hasil penjualan ayam juga semakin tinggi.

\section{Revenue Cost Ratio (R/C)}

Perdapat perbedaan antara $\mathrm{P} 0$ dan $\mathrm{P} 1$ dengan rataan $R / C$ P1 lebih tinggi dibandingkan dengan $\mathrm{P} 0$ (Tabel 1). Perbedaan yang terjadi disebabkan oleh faktor rataan biaya produksi P0 lebih tinggi dibandingkan dengan P1, dengan nilai Rp. 33.636 pada P0 dan biaya produksi P1 dengan nilai Rp. 31.584 sehingga selisih yang dihasilkan cukup besar yaitu Rp. 2.052, selisih yang dihasilkan terjadi karena pengunaan tepung kiambang terfermentasi yang menggantikan $10 \%$ pakan komersil. Rataan pendapatan tiap kelompok untuk kelompok P0 sebesar Rp. 39.753, kemudian untuk kelompok P1 sebesar Rp. 38.387 sehingga selisih yang dihasilkan yaitu Rp. 1.367. Maka R/C yang dihasilkan lebih tinggi pada P1 akibat biaya produksi yang digunakan lebih rendah dibandingkan dengan $\mathrm{P} 0$.

Revenue cost ratio yang rataan antara kelompok P0 senilai 1,180 dengan kelompok P1 senilai 1,215 memiliki selisih sebesar nilai sebesar 0,0348, bahkan r/c rataan yang dihasilkan pada kelompok P1 lebih tinggi dibandingkan P0. Hal ini disebabkan oleh biaya produksi yang lebih rendah pada P1 dibanding dengan P0 sehingga r/c yang dihasilkan lebih tinggi. Menurut Asnidar dan Asrida (2017) apabila nilai R/C > 1 maka usaha tersebut dikatakan untung dan layak untuk diusahakan, karena besarnya pendapatan lebih besar dari besarnya biaya yang dikeluarkan, dan sebaliknya. Jadi revenue cost ratio antara kelompok P0 dan P1 memiliki R/C > 1 sehingga dapat dikatakan bahwa usaha pemeliharaan tersebut layak untuk dilakukan. Oleh karena itu dapat dinyatakan bahwa biaya cost yang menghemat Rp. 2.052 dengan menggunakan tepung kiambang terfermentasi dapat menghasilkan pendapatan yang berbeda.

\section{Benefit Cost Ratio (B/C)}

Perbedaan antara $\mathrm{P} 0$ dan $\mathrm{P} 1$ dengan rataan $B / C$ yang dihasilkan lebih tinggi pada $\mathrm{P} 1$ dibandingkan dengan P0 (Tabel 1). Perbedaan yang terjadi disebabkan oleh faktor rataan keuntungan P0 dan P1 memiliki nilai sebesar Rp. 6.222 dan Rp. 7.146 dengan nilai selisih Rp. 685. Bahkan dari rataan tersebut P1 memiliki rataan keuntungan yang lebih tinggi dibandingkan dengan P0 karena biaya produksi P1 lebih rendah dibandingkan dengan $\mathrm{P} 0$, hal ini disebabkan penggunaan $10 \%$ tepung kiambang terfermentasi pada P1 memiliki nilai yang lebih rendah dibanding $\mathrm{P} 0$.

Hasil dari rataan B/C kelompok P0 dan P1 memiliki nilai selisih sebesar 0,0348. Hasil rataan pada P0 senilai 0,181 memiliki arti setiap pengeluaraan Rp. 1,- memiliki keuntungan Rp. 0,181,- dan rataan pada P1 senilai 0,215 memiliki arti setiap pengeluaraan Rp. 1,- memiliki keuntungan Rp. 0,215,-. B/C pada penelitian menunjukkan bahwa usaha ini layak untuk diteruskan.

\section{KESIMPULAN}

Berdasarkan hasil penelitian dapat disimpulkan bahwa penggunaan tepung kiambang terfermentasi pada ransum ayam Jawa super sebanyak 10\% dapat mengurangi biaya produksi dan memiliki nilai ekonomis. 


\section{DAFTAR PUSTAKA}

Ariyanti, R. 2014. Analisis break even point sebagai dasar pengambilan keputusan manajemen terhadap perencanaan volume penjualan dan laba (studi kasus pada PT. Cakra Guna Cipta Malang periode 20112013). Jurnal Administrasi Bisnis S1 Universitas Brawijaya 11(1): 82446.

Asnidar \& Asrida. 2017. Analisis kelayakan usaha home industry kerupuk opak di Desa Paloh Meunasah Dayah Kecamatan Muara Satu Kabupaten Aceh Utara. Jurnal S. Pertanian 1(1): 39-47.

Kaleka, N. 2015. Beternak Ayam Kampung Super Tanpa Bau. Arcitra. Solo.

Ketaren, P. P. 2010. Kebutuhan gizi ternak unggas di Indonesia. Wartazoa 20(4): 172-180.

Munawir, S. 2000. Analisis Laporan Keuangan. Liberty. Yogyakarta.

Rahardi dan Hartono. 1993. Agribisnis Peternakan. Penebar Swadaya. Jakarta.

Rasyaf, M. 2011. Panduan Beternak Ayam Pedaging. Penebar Swadaya. Jakarta.

Rizal, Y. 2006. Ilmu Nutrien Unggas. Andalas University Press. Padang.

Soeharjo dan Patong. 1973. Sendi-sendi Pokok Usaha Tani. Jurusan Ilmu-ilmu Sosial Ekonomi Pertanian. Fakultas Pertanian. Bogor: Institut Pertanian Bogor.

Yamin, M. 2008. Pemanfaatkan ampas kelapa dan ampas kelapa fermentasi dalam ransum terhadap efesiensi ransum dan income over feed cost ayam pedaging. Jurnal Agroland. 15 (2) : 135 - 139.

Zaman, Q., Suparno, G., dan Hariani, D. 2013. Pengaruh kiambang (Salvinia molesta) yang difermentasi dengan ragi tempe sebagai suplemen pakan terhadap peningkatan biomassa ayam pedaging. LenteraBio: Berkala Ilmiah Biologi. 2(1): 131-137. 